\title{
Lacanian Implications of Departures in Zemeckis's Beowulf from Beowulf, the Old English Epic
}

\section{ABSTRACT}

Although Robert Zemeckis's film Beowulf (2007) is a re-writing of the Old English epic Beowulf with a shifting of perspective, certain details in the film can only be understood by referring to the poem. That is, a better understanding of the film is tied closely to an awareness of certain narrative elements in the epic. The emphasis on Beowulf in the poem shifts to the Mother in the film. This shift obviously leads to a recontextualization of the narrative elements of the former text. In the epic, Grendel is left without a father; however, in the film, he is fathered by Hrothgar but this biological fathering does not lead to linguistic castration. In their case, things are reversed: rather than the infant being castrated by the Law/ language, the biological father is led to a psychic regression due to the son. This appears to be a dramatization of the conflicts between the $(\mathrm{m})$ Other and the shared Other/the representative of the paternal metaphor: that is, Hrothgar. This time, the (m)Other conquers the representative of the paternal metaphor and annuls his masculinity, which radically changes the way in which we evaluate the course of events in the film. These departures make more sense if they are analyzed against the background of Lacanian epistemology. This paper aims to explore the film's departures from the poem by approaching it from a Lacanian perspective.

Keywords: Beowulf, Zemeckis, adaptation, Lacanian criticism. 


\section{PREAMBLE}

Although Zemeckis's film Beowulf (2007) is a re-writing of the Old English epic Beowulf with a shifting of perspective, the film requires that we should closely consult the first third of the Old English epic in order to produce a comprehensive analysis of the adaptation. Without reference to the epic, certain elements in the film remain obscure because this text both took place within, and took off from, a dialogue with its times, and such a dialogue is never simple. For example, it may be difficult for us to understand why Beowulf risks his thanes' lives to kill this monster if we do not keep the heroic code of conduct and its ideals at the back of our minds, However, the stress I am putting on the similarities goes the other way as I intend to shed more light on the differences between these two texts against the background of the shared elements. Therefore, this essay engages with only the general aspects of these similarities, which I have taken up here in order to avoid giving an unbalanced perspective on the interpretation of the differences.

The course of the events in the film is shaped by a radical shift which foregrounds the psychodynamics of the characters. For this reason I aim to look at the film from a psychoanalytical vantage point in order to cast a new hermeneutical frame over it and to explore more of the resonances that are implied in the departures from the epic. In the film, Hrothgar's link with the imaginary seems to be integral to Grendel's subjectivity (or lack of it). In contrast to what happens in the heavily patriarchal discourse of the epic, in the film the (m)Other ${ }^{1}$ conquers the representative of the paternal metaphor. Accordingly, the emphasis on Beowulf in the poem shifts to the Mother in the film which problematizes what Grendel and the Dam desire rather than what Beowulf desires. In this process the film looks at the intricate psychodynamics between Grendel, the Dam, Hrothgar and Beowulf. In my analysis I will consult Lacanian epistemology for my conceptual framework as I believe that Lacanian epistemology can account for this intricacy better than other psychoanalytical perspectives, since, for Lacan, desire is external more than internal: “man's desire finds its meaning in the desire of the other, not so much because the other holds the key to the object desired, as because the first object of desire is to be recognized by the other" (Lacan, Language 31) and desire is generated through the psychodynamics and intrasubjectivity between the infant and the (m)Other. Following this line of thinking, I will explore the psychodynamics of the

In Lacanian epistemology, the Other has a double nature as "the Other as both 'inside' and 'outside'; as both 'discourse of the unconscious' and the social substance" (Hook 57). To avoid any conceptual confusion the first will be referred to as the (m)Other and the second as the shared Other or simply as the Other. 
relationship between Hrothgar, Beowulf and the Dam by referring to what Lacan said about the correlation between the paternal metaphor and the (m) Other. Grendel's situation in the film will be explored in the context of Lacanian ideas of linguistic castration and the significance of the logic of the signifiers.

\section{LACANIAN IMPLICATIONS OF THE SHIFTING OF THE PERSPECTIVE IN THE FILM}

From the meeting between Grendel's Mother and Beowulf on, the film arranges the narrative elements quite differently, to establish internal cohesion. Parallelisms between the film and the first third of the epic do not continue after Beowulf's meeting with the Mother/Dam, as the film radically departs from the text. However, the film continues to borrow and re-employ metaphors and imagery from its source. Despite strong parallelisms between the Old English epic and the early scenes of the film, there are substantial differences, too. The film presents the course of events from the Mother's perspective while the poem is told from the perspective of the Christian narrator (the metonymic extension of the Father) who appropriates Beowulf's struggle. As such, one text foregrounds feminine elements while the other represses them. The symbiosis between Grendel and the Dam is still intact in the film and

Grendel, who desires what the (m)Other desires, continues to hold phallic significance for his Mother. He remains as the subject without lack as it is in and through language that this intersubjective space is fabricated and as "external otherness, language" remains an impossibility in his world. In other words, while internal otherness is achieved in his world, external otherness is beyond his grasp. (Birlik 249)

In the Old English epic, Grendel is left without a father; however, in the film, as stated above, he is fathered by Hrothgar. In a comprehensive comparative analysis of Gunnerson's (2005) and Zemeckis's (2007) film adaptations, Hodapp attempts to answer the question "who is Grendel's daddy?" and tries to explain both the identity of the father and "in part Grendel's invasion of Heorot" (101). However, for Hodapp, the answers supplied to this question reveal more about the film's "twenty-first century audience than about the poem or its cultural level" (101). At this point I depart from Hodapp and suggest that the film problematizes the possible link between the (biological) father and the Father at the heart (Heorot) of this feudal organization. My emphasis falls on the father's (im) potency 
in representing the Law. In the film, Hrothgar's biological fathering is not imbued with linguistic castration, which implies the traumatic disconnection from the mother and submitting oneself to the logic of the signifiers determined by the paternal metaphor. In their case, things are reversed: rather than the infant being castrated by the Law/language, the biological father is led to a psychic regression due to the son (to be precise, due to the Dam's desire for a son). As the father's link with the imaginary seems to be kept intact in the film, it appears to be a dramatization of the conflicts between the $(\mathrm{m})$ Other and the shared Other/the representative of the paternal metaphor, that is, the king. This time, the (m)Other conquers the representative of the paternal metaphor and annuls his masculinity. In such a context, "[s] urprisingly, perhaps, the film's moral center, such as it is, lies not with the Danes or the Geats but more with Grendel's mother, who articulates the film's underlying point most clearly" (Hodapp 104). It comes as no surprise that the Mother's representation in the film is "the topic discussed most intensively by the scholars" (Traidl 132).

In both texts, the same opposition between the (m)Other and the paternal metaphor is established between the sea, which is identified with Grendel's Mother-who does not have a name (that is, who is not symbolically positioned or who exists outside language), and the land $\left(\right.$ or Heorot ${ }^{2}$-which is identified with the stable and the masculine. In other words, the phallic Other (represented by the sea/cave/the Mother) destabilizes the parameters and operating mechanisms of the Shared Other, the symbolic in Heorot. In the same line of thinking, both in the film and in the epic, space is presented in binary terms as this world and the underworld. This world is conquered by male phallic energy in both texts: however, in the first one, the paternal metaphor is represented by Hrothgar and Christ (due to the narrator's intrusions) and in the second one, despite the Christian priest in the presence of the king, the paternal metaphor remains unrepresented. In the epic, the underworld has Christian resonances as it is characterized by shadow, misty moors, perpetual darkness, demons, etc. This is the binary opposite of a world which is reigned over by God. This is the uncharted country, outside the Christian domain. In Swanton's words, Grendel "has made his home with all that is antithetical to Heorot," which means "heart" and which is "a major Germanic symbol of both regularity and purity" (56). In the film, Heorot and the cave come to represent the topological structure of consciousness and the unconscious, or the originary "object-seeking" drives. In this way, both of the texts proceed through binarisms which are

2 During the reign of Beowulf, instead of the mead-hall there is the stone castle, which, for Hodapp, is indicative of Beowulf's "worldly success” (106). 
based on spatial oppositions but the significance attached to these binaries differs due to the shifting perspective. These oppositions are darkness vs. light, death vs. life, mother vs. father, imaginary vs. symbolic, nature vs. culture, sea vs. land, pre-Oedipal vs. Oedipal, pre-linguistic vs. symbolic, ungendered vs. gendered, demon vs. Christian, the (m)Other vs. the Name of the Father. It is possible to extend this list based on the basic binary opposition between the sea and the land.

At the beginning of the film Beowulf says "I belong to the sea." Misleadingly, this statement sounds masculine as the sea is turbulent and suggests a harsh form of male life. However, in the course of the film, the connotations of the sea change significantly as it is everywhere: it is under the land and it surrounds the land. It is incomprehensible, indefinable, unfixed and amorphous, and Grendel's Mother lives in the sea. The sea and the way in which it is depicted reminds us of amniotic fluid and this idea is supported by two details in the film: when Beowulf steps into the sea of the underworld/cave/unconscious, the colour of the water changes. The water seems to react to something alien. Another detail is the liquid substance dripping from Grendel's mouth and body. His body seems to be covered in this substance. The sea seems to be associated with the Lacanian imaginary and Heorot embodies within itself phallocentric discourse that is conquered by the $(\mathrm{m})$ Other. At this point, examining the implications of these registers in Lacan might prepare the ground for a better understanding of Heorot, the sea and the cave in the film. Lacan makes a distinction between the imaginary and the symbolic registers but, at the same time, underlines that both are constitutive in the formation of the human subject. The concept of the Borromean knot reflects schematically how Lacan bases his register theory on the co-existence of three registers. This knot assumes an ontological significance as "in order to sustain consciousness, we must be capable of feeling (Imaginary), using language (Symbolic), and encountering surprise (Real)" (Brivic 12). They depend on each other "looping into each other in such a way that if any one is opened, the other will come apart" (Brivic 12). Their distinction and co-existence indicates that, unlike Freud, Lacan emphasizes the relational/identificatory processes to be experienced with the mother or with significant others. Lacan also metaphorizes the Freudian idea of the biological father and associates the Father (Law) with language or the logic of the signifiers: "Language, he describes, as an intersubjective order of symbolization, an order embedded within patriarchal culture, and thus a force that perpetuates that which he calls the 'Law of the Father"' (Elliott 105).

With language, the infant is integrated into a social and ethical system; this process can be taken as the acculturation process. Language is already there before the infant is born, and it regulates both the unconscious, 
conscious and social mechanisms. That is, both the internal and the external are constituted by language; therefore, "the law of man has been the law of language" (Lacan, Ecrits 225). In other words, for Lacan "it is the world of words that creates the world of things" and man "speaks but it is because the symbol has made him man" (Ecrits 229). The sense of wholeness/gratification enjoyed by the infant is disrupted by language as the infant internalizes or is encoded by the logic of the signifiers. In this line of thinking, both the film and the Old English text seem to provide an interesting corrective to classical Freudian theory, which tends to give prominence to the biological father in the constitution of the self, underestimating the significance of the mother and language in the process. When we look at two different depictions of Grendel and his Mother in these texts, we can say that in the Old English epic, the discourse within which the once omnipotent king is located is unable to define Grendel, his Mother and their whereabouts. The space in which they live is presented in extra-linguistic terms. The local people do not know the father of Grendel. Obviously there is the biological father but the Father remains dysfunctional in his world:

Land-people heard I, liegemen, this saying,

Dwellers in halls, they had seen very often

A pair of such mighty march-striding creatures,

Far-dwelling spirits, holding the moorlands:

One of them wore, as well they might notice,

The image of woman, the other one wretched

In guise of a man wandered in exile,

Except he was huger than any of earthmen;

Earth-dwelling people entitled him Grendel

In days of yore: they know not their father,

Whe'r ill-going spirits any were borne him

The inhabit the most desolate and horrible places.

Ever before. (Beowulf XXI 25-37)

In the film, Hrothgar, who is both the father and the representative of the Father, cannot organize the sliding signifiers in Grendel's world. Grendel cannot achieve linguistic closure, thus, repression cannot be constituted in his psyche. Therefore, Grendel's desire seems to be impersonal: he is not an object apart from the mother yet. The father, Hrothgar, and what he represents are the measure of all things in the epic, and the text is charged with masculine energy. However, in the film, we see a reversal of the traditional hierarchy between the Father and the (m)Other. In the film, Hrothgar, a metonymic extension of the Father, cannot exert his power and authority in the symbolic of Heorot, which is invaded by pre-symbolic 
elements that are also integral to Hrothgar's psyche. Therefore, in the film, when Grendel attacks the logic of the signifiers in its symbolic, as he is positioned elsewhere and speaks from elsewhere, he represents the

libidinal intensity prior to conceptual thought. He is the disruptive power of the unconscious in incarnate form which destabilizes the symbolic as he has not yet met the repressive closure of desire in the aftermath of the Oedipal process. As the Oedipal and the social condition have not yet inscribed the inside of his desire, he is the primary chaos of the pre-representation and pre-signification. As a result, he is still shapeless, distorted, not symbolically positioned and he can speak only as much as a two-year-old child can. (Birlik 247)

In Grendel's world the dominating element is not the $\mathrm{F} /$ father but the (m) Other. However, he wants to relate himself to the logic of the signifiers, or the symbolic represented by Hrothgar, and calls him "the father" in the way an infant does. What we hear from Grendel sounds very much like what Lacan terms the lalangue, the infant speech before it submits itself to the Law and before it is gendered, or the language through which the unconscious speaks (Nasio 51). Grendel's attacks then also objectify his search for an intrinsic link between his desire and the symbolic represented by his biological father. He wants to be acknowledged by Hrothgar and expects Hrothgar to act as the metonymic extension of the paternal metaphor in his case, too: "This might be the reason why he does not attack Hrothgar himself but kills his 'acknowledged sons' to whom Hrothgar grants recognition” (Birlik 248).

By way of conclusion, despite Grendel's and his Mother's attacks in the epic, the stability and phallogocentric discourse of the land is emphasized and Beowulf is an agent in this emphasis. In the film, this aspect of Beowulf undergoes a considerable change as the emphasis shifts onto the $(\mathrm{m})$ Other. Grendel cannot achieve the link with the symbolic and remains in symbiosis with the $(\mathrm{m})$ Other in the film. This is a far cry from the image of Grendel in the Old English epic, in which he is regarded as a descendant of Cain and is ostracized from the community for his nonChristian elements. Throughout, therefore, the film is dominated by the (m)Other, both the biological mother and what she represents.

\section{Works Cited}

Beowulf. Directed by Robert Zemeckis, performances by Ray Winstone, Antony Hopkins and Angelina Jolie, Paramount Pictures, 2007. Beowulf. Translated by Leslie Hall. D. C. Heath, 2005. 
Birlik, Nurten. "Hermeneutics of Lack of Lack and the Dyad of the (m) Other and the Shared Other, in Zemeckis's Beowulf." Neophilologus, vol. 102, no. 2, 2018, pp. 241-56. https://doi.org/10.1007/s11061-018-9552-1

Brivic, Shelly. Joyce through Lacan and Žižek: Explorations. Springer, 2008 Elliott, Anthony. Psychoanalytic Theory. Palgrave, 2002.

Hodapp, W. F. “"no hie fæder cunnon': But Twenty-first Century Film Makers Do.” Essays in Medieval Studies, vol. 26, 2010, pp. 101-08. https://doi.org/10.1353/ems.2010.0002

Hook, Derek. “Absolute other: Lacan’s 'big Other' as Adjunct to Critical Social Psychological Analysis?" Social and Personality Psychology Compass, vol. 2, no.1, 2008, pp. 51-73. https://doi.org/10.1111/j.17519004.2007.00067.x

Lacan, Jacques. Écrits. Translated by Bruce Fink. W. W. Norton, 2006.

Lacan, Jacques. The Language of the Self: The Function of Language in Psychoanalysis. Translated by A. Wilden. The Johns Hopkins UP, 1981. Nasio, Juan-David. Five Lessons on the Psychoanalytic Theory of Jacques Lacan. Translated by David Pettigrew and François Raffoul. State U of New York P, 1998.

Swanton, Michael. English Literature Before Chaucer. Longman, 1987. Traidl, Veronika. Telling Tales about Beowulf: The Poem and the Films. Herbert UtzVerlag, 2016. https://doi.org/10.1515/east-2017-0034

Prof. Dr. Nurten Birlik has been teaching as a senior instructor of English Literature, since 1997, in the Department of Foreign Language Education, Faculty of Education, Middle East Technical University, Ankara, Turkey. She has a book titled Coleridge's Conversation Poems and Poems of High Imagination. She has also co-authored a book titled Lacan in Literature and Film. She has published a number of articles on British Romantic Poetry and Lacanian theory. https://orcid.org/0000-0002-4544-9595 nbirlik@metu.edu.tr 